\title{
COLOUR SPLASH UNTUK MODEL PEREMPUAN DALAM FOTOGRAFI EKSPRESI
}

\author{
Sigit Setya Kusuma \\ Mahasiswa Program Studi Penciptaan Fotografi \\ Program Pascasarjana, ISI Yogyakarta \\ Jalan Suryodiningratan No. 8, Yogyakarta
}

No. Telp. (0274) 419791, No. HP.: 085708699994,E-mail: sigitsetyakusuma@gmail.com

\begin{abstract}
Abstrak
Penciptaan karya fotografi ini berjudul "Colour Splash untuk Model Perempuan dalam Fotografi Ekspresi”. Tujuan penciptaan karya fotografi ini untuk: (1) mendeskripsikan visualisasi respons colour splash dengan percikan air dan ledakan holi powder untuk objek model perempuan dalam karya fotografi ekspresi; (2) menjelaskan faktor yang mendukung sehingga karya colour splash dan objek perempuan menarik jika divisualisasikan menjadi karya fotografi ekspresi; dan (3) menjelaskan alasan colour splash dengan percikan air dan ledakan holi powder untuk objek perempuan menjadi daya tarik apabila dijadikan karya fotografi ekspresi. Metode yang digunakan dalam penelitian ini adalah metode observasi, dengan cara pengumpulan data, yaitu mengadakan pengamatan langsung terhadap suatu objek dalam suatu periode tertentu dan dengan merekam hal-hal tertentu yang diamati. Metode ini dilakukan dengan menjabarkan apa yang ingin disampaikan disertai dengan eksplorasi dan eksperimen terhadap objek, lokasi, alat, dan teknik yang akan dipakai dalam fotografi colour splash. Hasil dari penciptaan karya fotografi ini adalah penulis secara detail menjadi tahu tentang proses kreatif penciptaan karya fotografi seni. Bahwa ledakan warna dan percikan air yang berwarna bisa didukung oleh objek perempuan yang mampu menghasilkan foto yang bernilai artistik sekaligus menjadi pengalaman seni yang baru.
\end{abstract}

Kata kunci: colour splash, perempuan, fotografi ekspresi

\begin{abstract}
Color Splash for Female Models in Fine Art Photography. This creation of photography is entitled "Color Splash for Female Models in Fine Art Photography". The aims of this creation are (1) describing visual response towards color splash with water splash and holi powder explosion on the female models in the context of fine art photography; (2) explaining supportive factors which are able to make the female objects and the color splash look interesting visually in fine art photography; and (3) explaining the reasons why color splash with water splash and holi powder on the female objects become attractive in fine art photography. The method used in this research was the observatory method by means of collecting data, which were conducting direct observation of an object in a certain period of time and recording them. This method was conducted by describing everything which was needed to be delivered along with the exploration and experiment towards the objects, location, tools, and techniques used in color splash photography. This study resulting a deep knowledge of the creative process in fine art photography creation, that the color explosion and the colorful water splash could support the female photographic objects in order to create artistic photographs and whole new artistic experience.
\end{abstract}

Keywords: colour splash, female, fine art photography 


\section{PENDAHULUAN}

Terinspirasi dari warna-warna yang sering muncul dalam kehidupan sehari-hari dan ledakan-ledakan emosi perempuan, timbul ide untuk mencipta karya "Colour Splash untuk Model Perempuan dalam Fotografi Ekspresi". Selain media air dalam proses pembuatan karya seni fotografi, percikan atau ledakan warna (colour splash) menggunakan beberapa materi yang bisa menimbulkan ledakan yang bermacam-macam bentuk, yaitu tepung berwarna seperti tepung terigu (holi powder) dan cat.

Dalam karya fotografi ini colour splash dengan air, holi powder, dan cat menjadi objek utama dan ekspresi manusia menjadi pendukung dari objek. Holi dalam kamus bahasa adalah perayaan atau festival, di India holi digunakan untuk perayaan baik yang bersifat sedih maupun senang. Holi powder digunakan sebagai materi serbuk ledakan warna (colour splash) untuk dijadikan objek penciptaan karya seni yang mempunyai daya tarik karena holy powder bisa mempunyai kesan lembut ataupun kasar untuk colour splash. Begitu pula dengan air dan cat, yang juga memberikan efek keindahan, keunikan, dan menghasilkan bentuk yang menarik ketika dicipratkan sehingga memberikan pemaknaan tersendiri dalam setiap karya yang didapat pada saat pemotretan. Efekefek itulah yang nanti akan digunakan untuk mendukung pemotretan, serta ekspresi manusia yang dapat dikombinasikan dengan efek-efek colour splash. Menurut Soedjono:

Kreativitas manusia dalam
pemotretan memunculkan
kaidah-kaidah foto yang estetik
secara komposisi, pencahayaan,
dan ketajaman (depth of field).
Kaidah-kaidah foto estetika
dipadukan bersamaintuisi dengan
berolah kreasi pengungkapan

ekspresi diri dalam domain kesenian, terutama yang bernuansa seni visual (Soedjono, 2006:50).

Proses penciptaan karya seni ini didukung dengan eksplorasi cahaya buatan (lampu studio) yang diarahkan ke objek colour splash, yaitu manusia. Manusia di sini menjadi tambahan yang memiliki sifat dan karakteristik yang ekspresif. Manusia bisa mengeluarkan emosi dalam dirinya untuk merespons apa yang terjadi dan mengekspresikan apa yang dirasa.

Karya seni adalah ekspresi diri untuk melakukan sebuah kreasi untuk kepuasan pribadi, tanpa memperhitungkan untung atau rugi. Seni merupakan ungkapan pengalaman batin. Pengalaman tersebut kemudian dituangkan melalui berbagai media seni, yang akhirnya dapat dinikmati sebagai sebuah karya seni, bahkan penikmat sebuah keindahan karya seni merupakan bagian dari aktivitas sekaligus pengalaman emosi manusia, seperti diungkapkan oleh Djelantik(1997:27) mengenai situasi katarsis atau kelegaan emosional setelah manusia mengalami ketegangan, bahwa di samping menikmati keindahan dalam menyaksikan kesenian dengan rangsangan emosinya manusia mengalami katarsis sebagai pembersihan jiwa dirinya yang mempunyai efek pengobatan rohani.

Fotografi kerap dijadikan sebuah langkah baru dalam berekspresi untuk menciptakan sebuah komposisi visual, yang mengajak penikmatnya untuk berpikir kreatif (Bright, 2005:45). Berpikir untuk lebih jauh melihat kenyataan melalui bahasa gambar. Ada berbagai kenyataan ataupun representasi yang mampu diungkapkan melalui fotografi. Bahkan dalam perkembangan seni, fotografi menjadi 
seni yang ekspresif karena fotografi mampu menjadi bagian dari pencarian jati diri seorang fotografer. Menurut Soedjono:

"Ekspresi diri melalui medium fotografi seni bisa dicapai dengan berbagai cara, di antaranya dengan memilih objek-objek foto yang unik untuk ditampilkan menjadi karya foto yang 'one of a kind', penggunaan teknik khusus baik dalam pemotretan maupun dengan teknik kamar gelap merupakan satu cara yang lain; dan bisa juga dengan cara tertentu dalam upaya menampilkan karyanya atau 'way of representation"' (Soedjono, 2007:10).

"Fotografi seni menjadi salah satu media ekpresi yang dapat dibuat dengan berbagai konsep dan cara. Fotografi seni telah menjadi wahana untuk berolah kreatif bagi para fotografer yang ingin menorehkan 'belang/ loreng' dan 'gading' sebagai gaya pribadinya dalam dunia fotografi seni” (Soedjono, 2007:51).

Sebuah karya fotografi harus memiliki konsep yang matang dan pertimbangan nilai artistik. Banyak teknik yang digunakan oleh seorang fotografer untuk mendapatkan dan menghasilkan karya seni yang indah. Salah satunya adalah teknik stop action, yaitu teknik yang menghentikan objek yang bergerak atau objek yang bergerak dibekukan gerakannya. Hasil dari karya teknik stop action yang ingin diharapkan adalah ledakan holi powder (colour explosion). Selain itu, menghentikan momen dari peragaan seorang model ketika merespons serbuk ledakan yang dilempar, tentu akan memunculkan berbagai macam ekspresi yang diikuti oleh gesture tubuh dan momen inilah yang akan diabadikan dalam teknik stop action.
Colour splash menggambarkan air sebagai benda biasa dengan cara yang indah untuk menyampaikan emosi dan perasaan-perasaan tertentu. Air, cat, dan holi powder akan menjadi bentuk yang beraneka ragam ketika holi powder dilempar ke tubuh model.

Karya yang dibuat di sini adalah sebuah karya seni fotografi ekspresi. Perempuan identik dengan karya seni komersial, tetapi yang diangkat dalam karya adalah perempuan sebagai pendukung karya seni fotografi ekspresi. Seperti yang diungkapkan oleh Sumardjo (2000:74), "Ekspresi dalam seni adalah mencurahkan perasaan tertentu dalam suasana perasaan gembira. Perasaan marah atau sedih dalam ekspresi seni juga harus dilakukan pada waktu senimannya sedang "tidak marah atau sedih".

Ekspresi yang dimaksud bukan hanya ekspresi model perempuan sebagai objek, tetapi cipratan air dan ledakan holi powder yang mengenai model yang diharapkan. Ekspresi model perempuan dan colour splash yang dihasilkan menjadi satu kesatuan. Colour splash menjadi simbol yang mampu menggambarkan ekspresi dan bahasa keindahan yang ingin dihasilkan dalam seni fotografi.

Air, cat, dan holi powder menjadi unsur penting dalam karya ini. Percikan air yang dicipratkan dan holi powder yang mengenai tubuh model, tidak mengacu pada unsur serbuk atau airnya, namun yang dihasilkan dari cipratan air ledakan serbuk merupakan ungkapan dari sebuah ekspresi. Tanpa serbuk, air, dan cat yang dicipratkan tentu saja tidak ada bedanya dengan memotret model perempuan seperti pada umumnya. Ekspresi model dituangkan dalam bahasa tubuh seperti gerakan dan mimik wajah. Respons model perempuan inilah yang ingin diabadikan dalam sebuah momen dalam 
fotografi ekspresi. Respons yang dihasilkan oleh model perempuan terhadap percikan air dalam setiap pemotretan akan menentukan momen.

Momen adalah waktu yang pendek (Tim Penyusun Kamus Pusat Bahasa, 2008:78). Menurut $\mathrm{HCB}$, decisive moment bukan hanya menjepret dengan timing yang tepat, tetapi komposisi bentuk, garis, dan sebagainya juga harus akurat (http://www.infofotografi.com/ blog/2012/06/pelajaran-dari-fotografer-henricartier-bresson/, diakses pada 9 Augustus 2015, pukul 01:14 WIB).

Momen yang diharapkan adalah waktu yang menjadi satu kesatuan dalam objek fotografi. Momen yang dihasilkan fotografi inilah yang tidak bisa diulang pada waktu yang sama. Hal inilah yang membuat karya fotografi ekspresi dengan colour splash menjadi menarik karena yang dibutuhkan adalah kejelian membaca respons dan momen dalam hitungan seper sekian detik. Melalui momen inilah ditemukan kenikmatan dan keindahan seni fotografi.

Pembuatan karya ini juga tidak mengesampingkan komposisi. Menurut Sukarya (2009:45), "Komposisi adalah penggambaran dari cara unik untuk kita dalam melihat dan menerjemahkan pengalaman emosional kita saat itu. Bagaimana merekamnya, juga bergantung pada interpretasi pribadi kita yang khas".

\section{METODE PENCIPTAAN}

Fotografi ekspresi membutuhkan konsep yang matang. Sisi artistik tidak bisa diabaikan begitu saja. Begitu pula dengan pemilihan materi dan model yang akan digunakan. Fotografi ekspresi juga membutuhkan pengamatan yang dalam sekaligus membutuhkan eksplorasi sebagai sebuah karya fotografi seni. Berikut ini tahap-tahap penciptaan karya fotografi "Colour Splash untuk Model Perempuan dalam Fotografi Ekspresi”.

1. Metode Observasi

a. Menyusun Rancangan Penciptaan Rancangan penciptaan yang perlu dilakukan dalam penciptaan karya fotografi meliputi:

1) Memilih Topik

Topik yang dimaksud merupakan suatu bahasan utama atau bahasan pokok dalam sebuah karya Tugas Akhir. Pemilihan topik adalah tentang "Colour Splash untuk Model Perempuan dalam Fotografi Ekspresi”.

3) Membaca Literatur

Setelah dilakukan proses pemilihan topik, berikutnya membuat pertanyaan yang sesuai dengan topik penciptaan dan mencari referensi dari karya-karya yang sudah ada, yang memiliki kesamaan objek supaya memperkaya referensi dan informasi.

b. Menentukan Lokasi Penciptaan

Lokasi objek penciptaan dalam karya Tugas Akhir ini adalah di dalam studio dan di luar studio yang sudah dilengkapi dengan sarana dan perlengkapan teknis fotografi yang memadai.

2. Metode Eksplorasi

Sebelum proses eksekusi karya dimulai, ada beberapa hal yang perlu dilakukan, yaitu:

a. Memilih Model Perempuan

Memilih model menjadi pertimbangan penting dalam fotografi 
ekspresi karena setiap perempuan tentunya memiliki karakteristik yang berbeda-beda antara satu dengan yang lain. Pemilihan model perempuan ini dilakukan dengan casting, yang tentunya sudah dengan kriteria atau klasifikasi yang sudah ditentukan. Proses ini memang dilakukan secara selektif dan proporsional sesuai dengan konsep yang sudah dibuat sejak awal. Ciri-ciri model yang terpilih adalah mempunyai gejolak jiwa muda yang terlihat semangat, wajah yang masih segar, cantik, dan ekspresif.

Model yang dipilih untuk karya fotografi ini adalah perempuan karena perempuan mempunyai perasaan yang lebih sensitif daripada laki-laki. Di samping itu, ingin menonjolkan sisi kecantikan dan keindahan perempuan meski dengan bantuan make up sebagai pendukung ekspresi keindahan tersebut. Keindahan yang dimaksud adalah keindahan secara fisik melalui tubuh perempuan. Keindahan yang meliputi seluruh ekspresi yang dicurahkan oleh model perempuan. Momen yang dihasilkan model perempuan, cipratan air, dan ekspresi menjadi satu kesatuan momen yang dipotret oleh kamera.

b. Pengumpulan Data

Pengumpulan data merupakan tahapan terpenting dalam suatu penciptaan. Pengumpulan dapat dilakukan dengan berbagai metode seperti eksplorasi, observasi, seleksi model, wawancara dengan model, dan studi pustaka. Kegiatan ini dilakukan pada intinya untuk memperoleh data atau informasi yang memang benarbenar dibutuhkan.
Proses eksplorasi dilakukan dalam melakukan bentuk cipratancipratan air dan eksplorasi pewarna yang akan dipakai sebagai campuran air. Selanjutnya pada tahap berikutnya dilakukan dengan studi pustaka dengan membaca buku-buku ataupun teori keindahan yang membahas fotografi seni.

3. Eksperimentasi

Improvisasi memungkinkan melakukan berbagai eksperimen. Eksperimen dilakukan selama proses pemotretan dan proses pengolahan dalam software photoshop untuk membuat foto yang mempunyai kesan nilai artistik. Selain itu, eksperimen dilakukan untuk menemukan suatu komposisi yang mendukung nilai artistik dalam karya fotografi.

Ajidarma (2002:20) mengungkapkan bahwa objektivitas baru merupakan evaluasi dalam fotografi. Seperti yang terekspresikan dalam foto karya Paul Strand, bahwa esensi foto ini adalah desain abstrak, sama seperti objektivitas baru. Bercirikan disintegrasi konvensi yang telah diterima dalam seni. Komposisi dalam aturan tradisional disingkirkan untuk mencari jalan baru bagi ekspresi.

\section{PEMBAHASAN}

Proses dalam penciptaan sebuah karya fotografi bisa dengan membaca, melihat, mengamati, atau terinspirasi dari pengalaman hidup seseorang atau apa pun yang terjadi dalam lingkungan sosial. Di samping itu, individu manusia dibekali bakat atau talenta dan hobi yang bermacam-macam dan unik. 
Fotografi ekspresi yang ingin ditonjolkan, yaitu percikan air ataupun tumpahan air, merupakan simbol tentang curahan emosi. Tentunya karya fotografi ini adalah bagian dari cara bebas berekspresi dan kepuasan dalam bereksplorasi. Fotografi ekspresi ini dibuat dengan konsep tertentu dan prosesnya tentu saja merupakan pilihan ekspresi berdasar pemotretnya. Dalam karya ini sengaja mengeksploitasi air sebagai objek utama dan model perempuan sebagai pendukung. Perihal fotografi menjadi medium ekspresi diri, juga ditegaskan oleh Soedjono (2006:27) dalam bukunya berjudul Pot Pourri Fotografi, "Sebuah karya fotografi yang dirancang dengan konsep tertentu dengan memilih objek foto yang terpilih dan yang diproses dan dihadirkan bagi kepentingan si pemotretnya dengan luahan ekspresi artistik dirinya, maka karya tersebut bisa menjadi sebuah karya fotografi ekspresi".

Dalam karya ini air dan holi powder memiliki sifat fleksibel yang akan mengikuti bentuk sesuai dengan benda itu berada. Selain model perempuan, warna menjadi pendukung holi powder dan air yang sesuai dengan konsep sehingga warna menjadi ungkapan ekspresi model yang dikonsep dalam visualisasi dengan media fotografi. Di situlah ekspresi model tertangkap dan tentunya bereaksi sehingga menghasilkan foto yang artistik. Acuan dalam mengambil topik tentang percikan air dan model perempuan ini juga didapat dari pengamatan tentang karya fotografi luar negeri yang menjadi referensi. Mengamati karya fotografi juga merupakan bagian dari apresiasi seni. Apresiasi bukan sekadar pasif, namun ada proses penikmatan. Menurut Kartika (2007:29), penikmatan merupakan proses dimensi psikologis, proses interaksi antara aspek intrinsik seseorang terhadap sebuah karya estetik.
Percikan warna dari air dan ledakan warna dari holi powder, jika dibidik dan dipotret dalam keadaan diam (stop action) bisa membentuk berbagai macam bentuk yang tidak bisa diduga sebelumnya. Ditambah dengan model perempuan yang akan mendukung sebagai bagian dari objek untuk menambah kesan artistik. Model perempuan yang memperagakan ekspresi saat terkena percikan air dan holi powder menjadi tantangan dan sensasi tersendiri. Dalam hal ini kreativitas digunakan untuk mengeksplorasi objek agar mendapatkan hasil foto yang sesuai dengan konsep yang diinginkan.

Kecantikan model perempuan akan menambah komposisi artistik dalam merespons percikan air. Kecantikan dan ekspresi yang dimaksud ialah ketika momen yang terjadi bersamaan antara ekspresi perempuan, cipratan air, dan holi powder sehingga respons yang kemudian membentuk gesture yang ditangkap dalam fotografi colour splash dengan teknik stop action, yaitu ketika momen ekspresi yang tidak bisa diulang atau hanya terjadi sekali dalam pemotretan.

Adapun model yang dipilih adalah perempuan dengan umur 22-27 tahun karena usia tersebut merepresentasikan jiwa muda yang berenergi dan segar. Cipratan air yang menyimbolkan keceriaan, semangat jiwa muda, kebahagiaan, amarah, senyum, dan kesedihan selalu dikaitkan dengan perempuan karena perempuan dalam kehidupan mudah untuk mengeluarkan air mata baik ketika senang, bahagia, marah, dan sedih. Melihat perempuan sangatlah menarik untuk dijadikan pendukung objek karya fotografi.

Ide penciptaan dalam karya ini akan menghasilkan foto dengan momen yang tidak bisa diulang dan hanya terjadi satu kali dalam 
hitungan waktu sehingga mengombinasikan bentuk respons model perempuan secara psikologis ketika permukaan kulitnya menanggapi cipratan air. Ditambah dengan ekspresi wajah model perempuan yang akan menggunakan make up untuk menjadi pelengkap kecantikan parasnya. Harapannya karya fotografi ini akan mempunyai daya tarik tersendiri dan mempunyai nilai artistik.

Penciptaan karya seni fotografi membutuhkan kejelian, wawasan, dan pengalaman berkesenian dalam kehidupan sehari-hari sehingga tumbuhlah sebuah ide penciptaan. Selain itu, penciptaan juga harus memiliki kreativitas untuk melihat sebuah fenomena yang dapat menjadi sebuah karya seni, untuk selanjutnya diaktualisasikan menjadi sebuah karya seni dengan berbagai langkah sehingga karya dapat diwujudkan.

Dari proses perwujudan karya tercipta empat karya colour splash dalam fotografi ekspresi. Dari masing-masing karya akan diulas satu per satu meliputi deskripsi karya dan teknik dari proses karya tersebut.

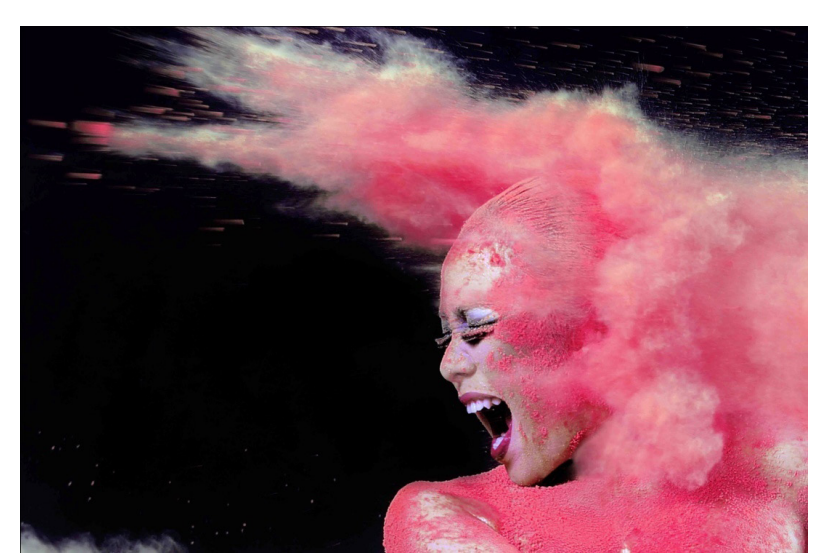

Karya Foto 1

Judul: Scream Girl

Ukuran karya 50x75 cm

Cetak digital pada kertas glossi laminasi doff

2016
Karya ini memvisualkan seorang perempuan yang sedang berteriak dan dicipratkan holi powder berwarna merah muda dengan background hitam. Karya ini mengungkapkan pelampiasan emosi yang lepas dengan teriakan atau jeritan model perempuan yang lepas. Curahan emosi dengan teriak ini menjadi hal yang banyak dilakukan ketika sedang merasakan kepenatan, kesedihan, ketakutan, dan curahan emosi lain. Warna yang dihasilkan dengan teknik high speed ini berpengaruh terhadap kepribadian perempuan. Warna merah muda memperlihatkan kecantikan dari seorang perempuan dan merah muda mempunyai kesan seorang perempuan. Pemotretan ini dilakukan di dalam studio dengan setting-an beberapa lighting.

Proses pemotretan ini dilakukan di dalam studio dengan posisi kamera di depan, memakai kamera Canon EOS 6D dan lensa 70200 dengan jarak 3 meter dari objek model, air yang dicipratkan dari samping kanan $45^{\circ}$ dan samping kiri $315^{\circ}$ dari model.

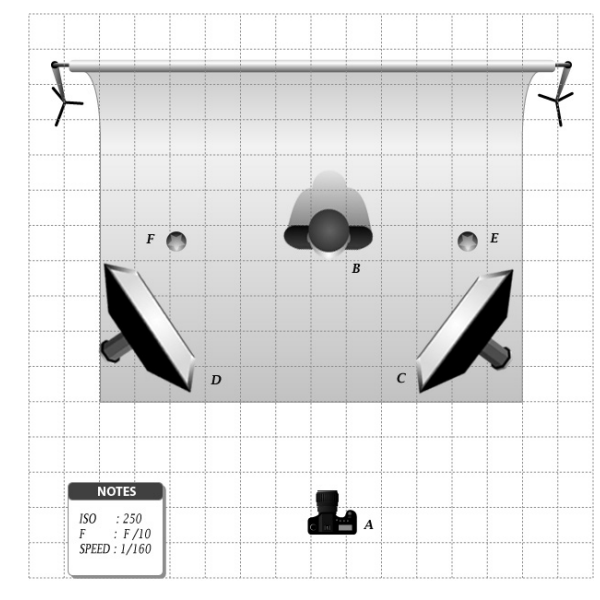
A : kamera
B : model
C : lighting (softbox)
D : lighting (softbox)
E : arah cipratan holi powder
F : arah cipratan holi powder 
Memakai 2 lighting dengan softbox yang bertujuan agar objek model terlihat beauty dan soft, juga serbuk holi yang dihasilkan tertangkap jelas dan sedikit melambat atau bergerak, di depan 1 lighting softbox dengan posisi yang pertama $45^{\circ}$ untuk memberikan cahaya pada muka dan tubuh serta mengeluarkan cahaya yang ingin menimbulkan sedikit tekstur atau detail objek model dan holi powder. Setelah itu 2 lighting softbox di depan samping kiri 1 dengan posisi $315^{\circ}$ sama halnya seperti posisi $45^{\circ}$ untuk memberikan cahaya pada muka dan tubuh serta mengeluarkan cahaya yang ingin menimbulkan sedikit tekstur atau detail objek model dan holi powder.

Karya foto 2 adalah objek perempuan yang dicipratkan air dengan background hitam. Karya berjudul Fresh ini bercerita tentang ekspresi kesegaran yang dirasakan oleh model perempuan dari colour splash. Percikan air menjadi simbol dari ekspresi yang dirasakan oleh model perempuan. Dalam foto ini digunakan teknik water splash yang memberhentikan objek yang bergerak. Objek yang bergerak cepat dan dihentikan dalam foto ini adalah holi powder. Tekstur atau detail dari percikan air sangat jelas karena teknik high speed (stop action) ini menggunakan beberapa flash lighting. Flash lighting ini mempunyai karakter flash duration, yaitu bisa memberhentikan objek yang bergerak cepat menjadi berhenti dengan ketajaman yang jelas.

Proses pemotretan ini dilakukan di dalam studio untuk posisi kamera di depan dengan memakai kamera Canon EOS 6D dan lensa 70-200 dengan jarak 3 meter dari objek model, air yang dicipratkan dari samping kanan $45^{\circ}$ dan samping kiri $315^{\circ}$ dari model.

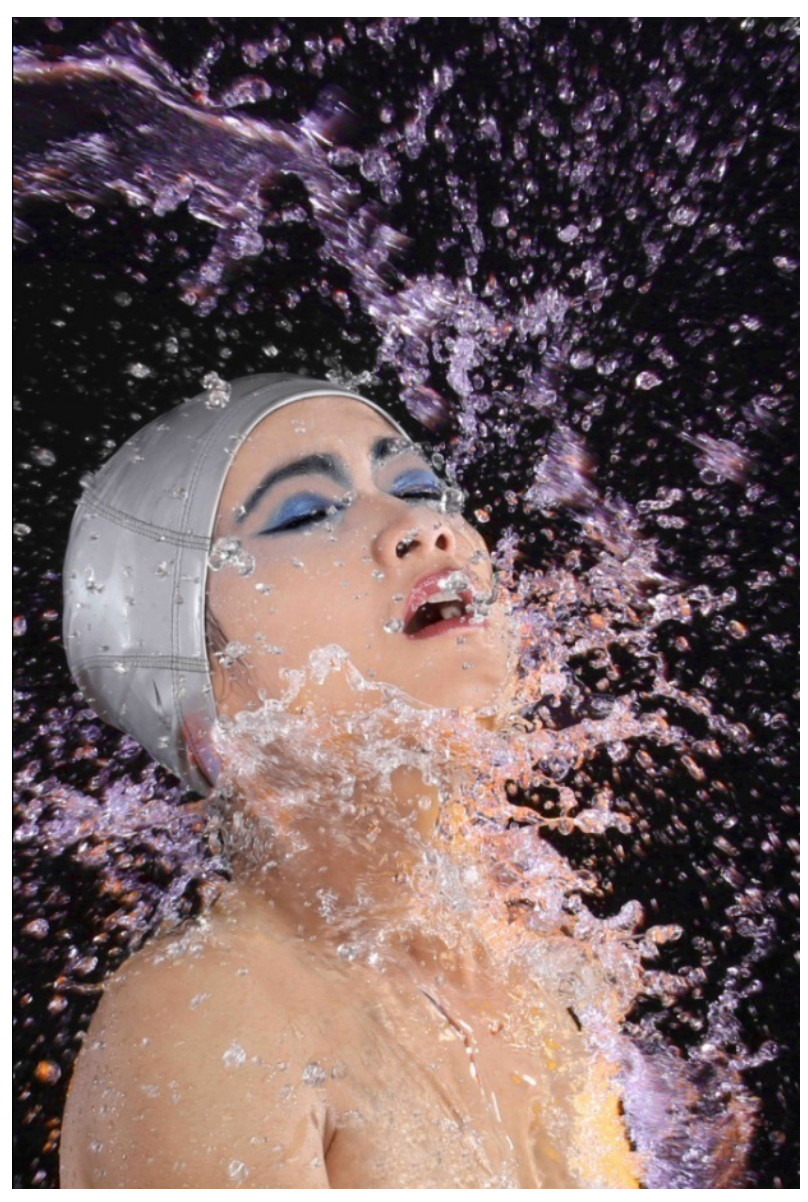

Karya Foto 2

Judul: Fresh

Ukuran karya $75 \times 50 \mathrm{~cm}$

Cetak digital pada kertas glossi laminasi doff 2016

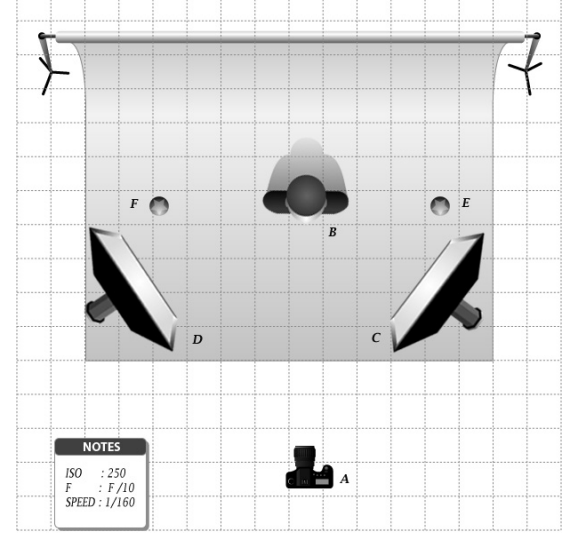
A : kamera
B : model
C : lighting (softbox)
D : lighting (softbox)
E : arah cipratan air
F : arah cipratan air 
Memakai 2 lighting dengan softbox yang bertujuan agar objek model terlihat beauty dan soft, juga cipratan air yang dihasilkan tertangkap jelas dan sedikit melambat atau bergerak, di depan 1 lighting softbox dengan posisi yang pertama $45^{\circ}$ untuk memberikan cahaya pada muka dan tubuh serta mengeluarkan cahaya yang ingin menimbulkan sedikit tekstur atau detail objek model dan air. Setelah itu 2 lighting softbox di depan samping kiri 1 dengan posisi $315^{\circ}$ sama halnya seperti posisi $45^{\circ}$ untuk memberikan cahaya pada muka dan tubuh serta mengeluarkan cahaya yang ingin menimbulkan sedikit tekstur atau detail objek model dan air.

Dalam karya foto 3, objek perempuan sendiri dan diam dengan dicipratkan air berwarna ungu dan merah muda dengan background hitam. Karya yang berjudul Enchanting Women ini menunjukkan perempuan yang anggun, cantik, dan menarik. Ekspresi model perempuan ini terlihat santai dan memperlihatkan kecantikan dan ketegarannya. Perpaduan dua warna antara merah muda dan ungu melambangkan sifat wanita yang anggun dan eksotis sehingga menjadikan wanita ini memesona dengan ekspresi diam. Komposisi dalam percikan air ini adalah percampuran antara air, tepung, dan pewarna. Percampuran tepung dengan air membuat kekentalan yang dihasilkan oleh percikan air memunculkan efek yang beraneka bentuk.

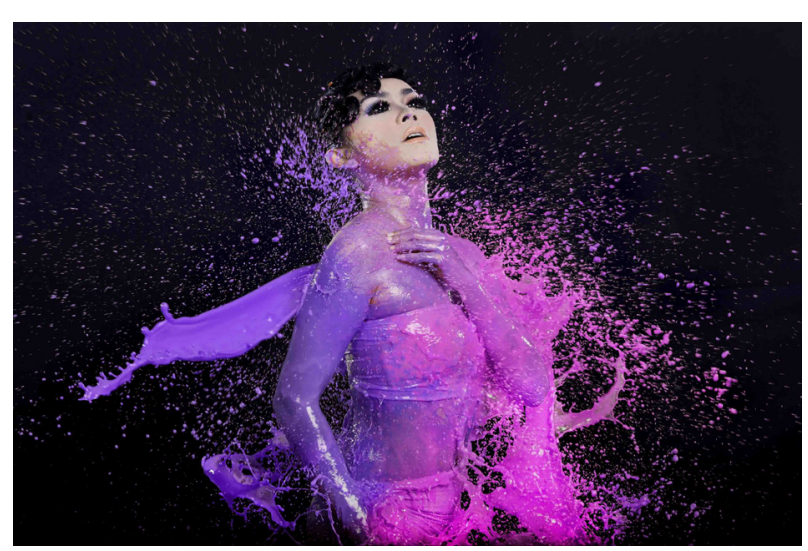

Karya Foto 3

Judul: Enchanting Women

Ukuran karya $50 \times 75 \mathrm{~cm}$

Cetak digital pada kertas glossi laminasi doff 2015

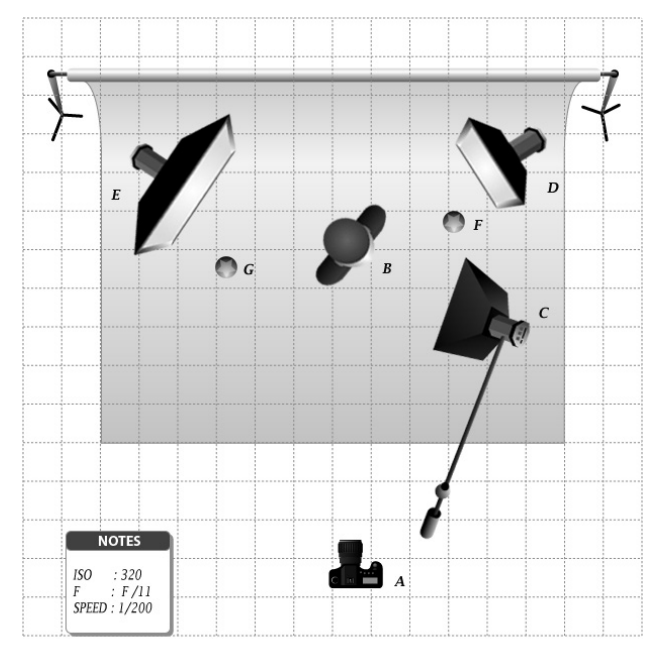
A : kamera
B : model
C : lighting (softbox)
D : lighting (softbox)
E : lighting (softbox)
F : arah cipratan air
G : arah cipratan air

Proses pemotretan dilakukan di dalam studio. Alasan mengambil background hitam ini adalah agar detail cipratan air bisa tertangkap jelas. Untuk posisi pemotretan kamera di depan objek dengan memakai kamera Canon EOS 6D dan lensa 70-200 dengan jarak 3 meter dari objek model, air yang dicipratkan dari dua arah, yaitu samping kanan $90^{\circ}$ dan samping kiri $270^{\circ}$ model. Untuk pencahayaan memakai 3 lighting, 
yaitu 3 softbox yang bertujuan agar cipratan air dan model lebih halus dan tidak menghilangkan detail dan tekstur airnya. Satu lighting softbox di posisi $45^{\circ}$ bertujuan untuk memberi cahaya di bagian muka dan agar terlihat lebih soft dan beauty. Lighting softbox di posisi $135^{\circ}$ bertujuan untuk memberi cahaya di bagian belakang kanan objek dan memperlihatkan detail dan tekstur colour splash. Lighting softbox di posisi $225^{\circ}$ bertujuan untuk memberi cahaya di bagian belakang kiri model dengan soft dan tetap memperlihatkan detail tekstur colour splash.

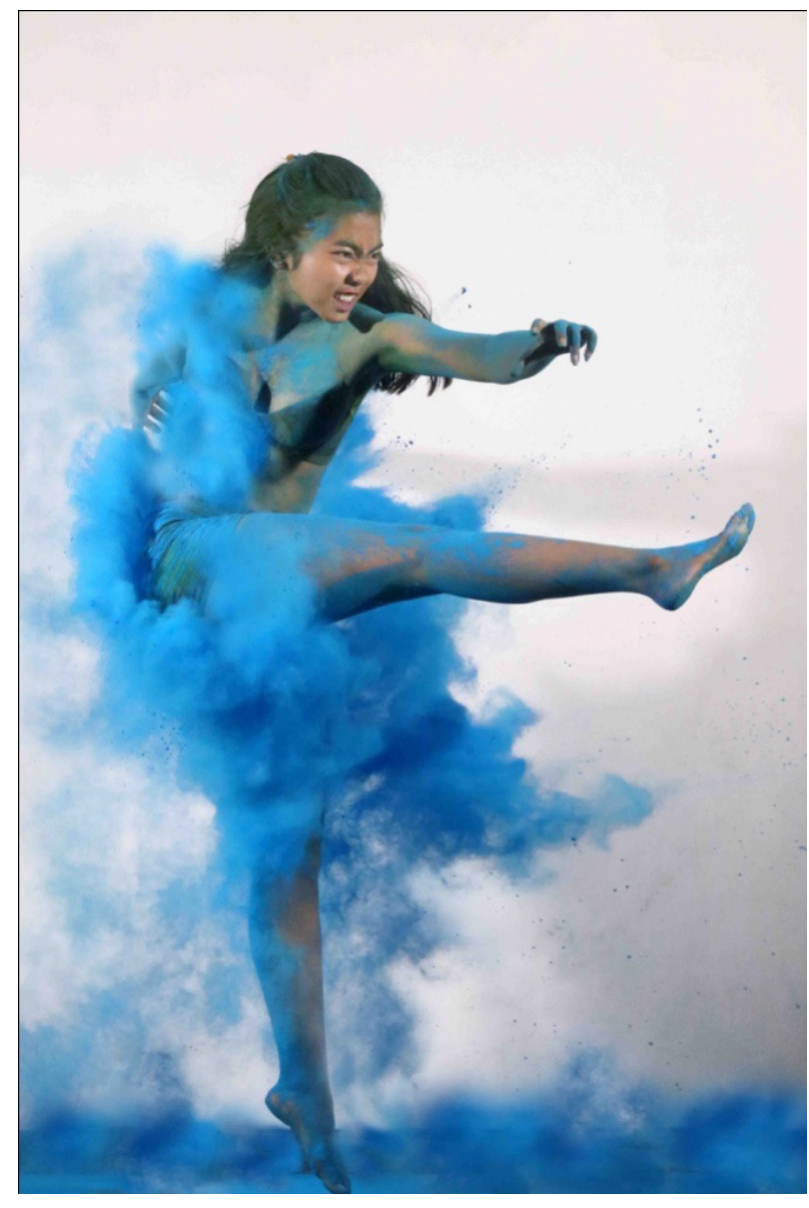

Karya Foto 4 Judul: Body Move

Ukuran karya $75 \times 50 \mathrm{~cm}$

Cetak digital pada kertas glossi laminasi doff 2016
Dalam karya foto 4, objek seorang perempuan yang dicipratkan holi powder berwarna biru sedang berteriak dengan melakukan gerakan tangan dan kaki yang ekspresif. Karya ini mengungkapkan ekspresi tentang gerak tubuh dengan ledakan holipowder. Gerak tubuh merupakan sebuah curahan emosi tentang ekspresi tubuh yang dirasakan. Ledakan holi powder menjadi pelengkap dalam ekspresi ini. Warna biru merupakan warna yang dingin, tetapi tidak semua warna biru menjadi dingin. Warna biru bisa juga menjadi warna yang panas untuk pengungkapannya. Pemotretan ini dilakukan di dalam studio dengan beberapa arah lighting.

Proses pemotretan ini dilakukan di dalam studio untuk posisi kamera di depan dengan memakai kamera Canon EOS 6D dan lensa 70-200 dengan jarak 3 meter dari objek model, air yang dicipratkan dari samping kanan $45^{\circ}$ dan samping kiri $315^{\circ}$ dari model.

Memakai 2 lighting dengan softbox yang bertujuan agar objek model terlihat beauty dan soft, juga holipowder yang dihasilkan tertangkap jelas dan sedikit melambat atau bergerak, di depan 1 lighting softbox dengan posisi yang pertama $45^{\circ}$ untuk memberikan cahaya pada muka dan tubuh serta mengeluarkan cahaya yang ingin menimbulkan sedikit tekstur atau detail objek model dan serbuk holi, setelah itu depan 2 lighting softbox di depan samping kiri 1 dengan posisi $315^{\circ}$ sama halnya seperti posisi $45^{\circ}$ untuk memberikan cahaya pada muka dan tubuh serta mengeluarkan cahaya yang iningin menimbulkan sedikit tekstur atau detail objek model dan holi powder. 


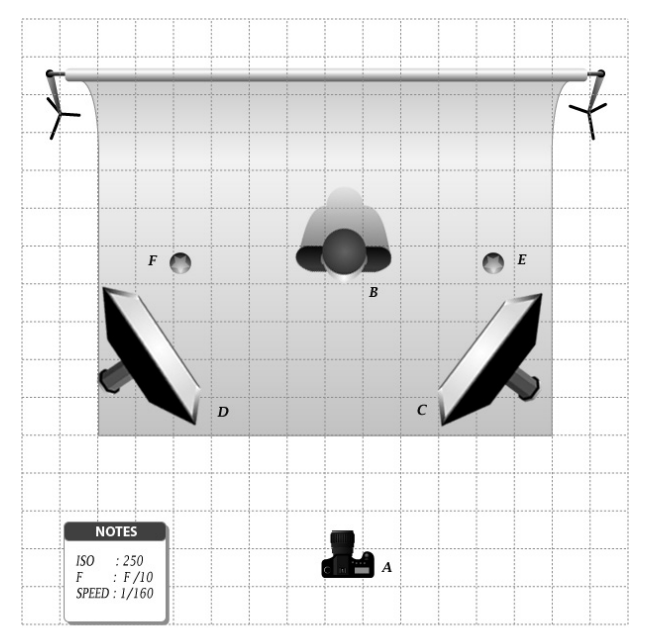
A : kamera
B : model
C : lighting (softbox)
D : lighting (softbox)
E : arah cipratan holi powder
F : arah cipratan holi powder

\section{SIMPULAN}

Fotografi seni yang menitikberatkan fotografi ekspresi memang memiliki tantangan tersendiri. Konsep dan perwujudannya harus berjalan sedemikian rupa dan harus seimbang. Konsep itu harus dijabarkan secara detail dan terencana dengan baik karena konsep menjadi acuan penting dalam melakukan eksekusi foto. Tantangan terbesar muncul dari tahapan eksplorasi foto yang dilakukan. Karena setiap momen yang dihasilkan antara satu dengan yang lain berbeda, tahapan eksplorasi dan eksperimentasi perlu dilakukan dengan sabar.

Visualisasi colour splash dalam fotografi adalah menciptakan berbagai efek dan karakter colour splash yang menarik sehingga memberikan kesan estetik dan ekspresif dalam karya. Dalam proses pembuatan karya ini, percikan warna yang dihasilkan dari berbagai arah cipratan ke arah model perempuan menjadikan efek tersebut bertekstur dan detail dari percikan warna terlihat jelas, sehingga eksperimen dan eksplorasi percikan warna menghasilkan bentuk yang beraneka ragam.

Karya "Colour Splash untuk Model Perempuan dalam Fotografi Ekspresi" dalam proses penciptaannya membutuhkan persiapan yang dilakukan dengan baik. Persiapan yang dilakukan meliputi pengumpulan data seperti pemilihan model perempuan secara selektif, pemilihan warna untuk campuran air, pengarahan kepada model, teknik membuat cipratan air, pengolahan teknik kamera, sampai dengan ketepatan dalam memotret momen yang dihasilkan yang tidak bisa diulang ke sekian kalinya. Hasil karya fotografi ekspresi yang diciptakan memiliki nilai keindahan dan artistik tertentu.

Pembuatan karya fotografi ini menemukan kesulitan bagaimana menjaga mood model agar tetap nyaman ketika tubuhnya merasakan kotor dengan holi powder dan basah dengan air. Di samping itu, kondisi fisik model perempuan yang harus benar-benar fit karena bersentuhan dengan holi powder dan air dalam jangka waktu selama pemotretan berlangsung. Hal ini memang tidak mudah dilakukan meskipun menemukan bagaimana melakukan pendekatan secara komunikatif dengan model. Oleh karena itu, kondisi fisik dan kenyamanan model perlu diperhatikan dengan baik. Jangan sampai emosi seorang model menjadi pengaruh terhadap ekspresi yang dimunculkan sehingga memengaruhi hasil foto yang diinginkan. Kesulitan selanjutnya yang dialami adalah ketika berkonsentrasi untuk menghasilkan efekefek percikan yang menarik dan berkoordinasi dengan pelempar air dan holi powder untuk ketepatan melempar saat komando dari fotografer. 


\section{KEPUSTAKAAN}

Ajidarma, Seno Gumira. 2002. Kisah Mata: Perbincangan tentang Ada. Yogyakarta: Galang Press.

Bright, Susan. 2005. Art Photography Now. New York: Aperture.

Djelantik, A.A. Made. 1999. Estetika Sebuah Pengantar. Bandung: MSPI.

http://www.infofotografi.com/blog/2012/06/ pelajaran-dari-fotografer-henricartier-bresson/ yang diakses pada 9 September 2016, pukul 01:14 WIB.

Kartika, Dharsono Sony. 2007. Kritik Seni. Bandung: Penerbit Rekayasa Sains Bandung.

Sukarya, Daniek G. 2009. Dalam Fotografi dan Stok Foto. Jakarta: PT Elex Media Komputindo Kompas Gramedia.

Tim Penyusun Kamus Departemen Pendidikan Nasional. 2008. Kamus Besar Bahasa Indonesia. Jakarta: PT Gramedia Pustaka Utama, Jakarta.

Soedjono, Soeprapto. 2006. Pot-Pourri Fotografi. Jakarta. Universitas Tri Sakti.

Sumardjo, Yakob. 2000. Filsafat Seni. Bandung: Penerbit ITB. 